\title{
La Representación de Hugo Chávez en la Revista Memorias de Venezuela (2008-2012)*
}

\author{
Hugo Chavez's representation in Memorias \\ de Venezuela journal (2008-2012)
}

Martha Lucía Márquez Restrepo***

Recibido: 29/01/2014

Aprobado: 18/03/2014

Disponible en línea: 01/07/2014

\section{Resumen}

Enmarcado en la disputa suscitada en Venezuela entre los historiadores de la Academia Nacional de Historia y los del Centro Nacional de Historia creado por el gobierno de Hugo Chávez en 2007, este artículo indaga sobre la forma como se representa el poder, en particular el Presidente Hugo Chávez, en 24 revistas de la serie Memorias de Venezuela. El análisis se apoya en la teoría sobre la representación de Louis Marin y de Roger Chartier, así como en las formas de dominación de Max Weber. Como metodología se usa el análisis estructural de contenidos.

\section{Palabras claves:}

Venezuela; Hugo Chávez; Centro Nacional de Historia; legitimidad; representación del poder

\begin{abstract}
Framed in the dispute arisen in Venezuela among historians from the National Academy of History and the National History Center created by Hugo Chavez's government in 2007, this article inquires how power is represented, particularly in the case of President Hugo Chavez, in 24 magazines from Memorias de Venezuela. The analysis is supported on the theory about representation from Louis Marin and Roger Chartier, and on the kinds of domination worked by Max Weber. The methodology used is structural content analysis.
\end{abstract}

\section{Keywords:}

Venezuela; Hugo Chávez; National History Center; legitimacy; representation of power

doi:10.11144/Javeriana.PAPO19-2.rhcr

${ }^{*}$ Artículo de Reflexión.

** Profesora de planta de la Universidad Javeriana de Bogotá, Facultad de Ciencia Política y Relaciones Internacionales. Correo electrónico: marquezm@javeriana.edu.co 


\section{Cómo citar este artículo:}

Márquez, M. L. (2014). La Representación de Hugo Chávez en la Revista Memorias de Venezuela (2008-2012). Papel Político, 19(2). pp. 527-56o. http://dx.doi.org/10.11144/ Javeriana.PAPO19-2.rhcr 


\section{Introducción}

El 6 de diciembre de 1998 el ex militar Hugo Chávez Frías ganó las elecciones en Venezuela al obtener 56,6\% de la votación. Su triunfo se apoyó en un discurso que proponía rescatar el ideario de tres figuras del pasado (Simón Bolívar, Simón Rodríguez y Ezequiel Zamora) para refundar tanto la nación como el viejo orden político, 'el puntofijismo', régimen que se había construido desde la transición a la democracia en 1958 y que se denunciaba como corrupto y antipopular.

El día de su posesión Hugo Chávez juró ante ‘la moribunda constitución de 1967’ y dio inicio al proceso de convocatoria de una asamblea nacional constituyente que en 1999 aprobó la carta magna de la V República, que recibió el nombre de República Bolivariana de Venezuela. Este fue el inicio de un proceso de refundación en el que no solo se cambió el nombre y la organización del Estado, sino el modelo de participación política que, de democracia representativa pasó a llamarse ‘democracia participativa y protagónica'; la política exterior que se diseñó para hacerle contrapeso al poder norteamericano favoreciendo el multipolarismo; y el modelo económico que desde 2006 transitó hacia lo que el gobierno ha llamado 'el socialismo del siglo XXI'.

Dentro de este conjunto de transformaciones Hugo Chávez ha pretendido también refundar la historia venezolana con el fin de legitimar su proyecto político². Para ello ha denunciado lo que llama 'la historia burguesa', 'la otra historia' o 'el discurso histórico tradicional', aludiendo a la historia realizada por historiadores tradicionales, entre ellos los de la Academia Nacional de Historia. Según el gobierno esa historia, escrita por las élites, ha ocultado el verdadero carácter y las hazañas de los héroes del pueblo como Simón Bolívar, Ezequiel Zamora y Cipriano Castro. Dice Chávez:

\section{[...] la historia [...] generalmente la escriben los vencedores, la historia oficial la escriben los vencedores. Los perdedores no escriben la historia oficial y entonces viene impregnada de la visión de quién la escribe, de la subjetividad de quién la escribe; y a Zamora, por supuesto, lo maltrató la oligarquía. (Chávez, 2001 febrero 1)}

Sobre esta denuncia, Hugo Chávez ha puesto a circular a través de sus discursos su propia versión de la historia de Venezuela cuya característica central es la construcción de un arco temporal que une el proceso de independencia de España y la revolución bolivariana, planteando que dado que la primera quedó inconclusa a causa

\footnotetext{
${ }^{1}$ Sobre el ascenso de Hugo Chávez al poder y el rumbo que tomó el proceso puede verse: Medina, M, López-Maya, M. y Lander, L. (2007, pp. 11-27), Medina, M. (2001), López-Maya, M. (2008; 2010). 2 Sobre el uso de la historia en el discurso de Hugo Chávez se puede consultar: Gómez, A. (2005), Langue, F. (2008; 2009; 2011).
} 
de la traición de las oligarquías venezolanas a Bolívar y su sueño de integración y de justicia social, la revolución bolivariana debe retomar esos ideales (Narvaja de Arnoux, 2008). Su versión de la historia se centra en el período de la independencia siendo una historia de batallas en la que se exalta a los hombres de armas. Adicional a esto, el gobierno creó en el año 2007 el Centro Nacional de Historia (CNH) con el fin de "Impulsar las políticas del Estado Revolucionario Bolivariano, destinadas a liberar la conciencia histórica y fortalecer la identidad nacional y nuestroamericana, para la construcción de la patria socialista” (Ministerio del Poder Popular para la Cultura, 2012). El CNH ha publicado un gran volumen de libros y un conjunto de revistas, entre ellas Memorias de Venezuela.

Los historiadores vinculados al Centro Nacional de Historia han sido denunciados por sus colegas de la Academia Nacional de Historia por su servicio al poder y hasta calificados por algún estudioso como "caudillos intelectuales del régimen” (Tillman, 2012). La revista Memorias de Venezuela a su vez, ha sido calificada como "la referencia oficial de la propaganda ideológica de la nueva historia" (Almarza, 2011). Sin embargo, una revisión atenta sugiere algún distanciamiento entre la versión de la historia de Venezuela de Hugo Chávez y la del $\mathrm{CNH}$, pues en tanto la primera se centra en los episodios de guerra en los que se exaltan a los hombres de armas, Memorias de Venezuela dedica en sus números sesiones al mundo indígena, la colonia, la conquista, el siglo XX y XXI y a la historia de la cultura, destacando la acción, no solo de los héroes de la patria sino de los negros, los indígenas, las mujeres y otros grupos subalternos.

A favor de este indicio de que la revista no es una burda reproducción del discurso del ex presidente, se puede también aducir que entre sus fundadores se encuentra un grupo de reconocidos intelectuales de amplia trayectoria que aunque han estado cercanos al proyecto político del ex presidente, no han dejado de manifestar algunas críticas al chavismo ${ }^{3}$. No indagar sobre la sospecha de estas diferencias sería caer en el prejuicio que denuncia Cristóbal Valencia de creer que los llamados chavistas son un grupo de pobres, ignorantes y ciegos seguidores de un líder (Valencia, 2005), cuando en realidad, si se estudia la historia del movimiento desde la formación de la logia conspiradora llamada MBR-2004, se puede ver que en la construcción del proyecto político participaron intelectuales y líderes, no solo de distintas procedencias -unos

\footnotetext{
${ }^{3}$ En 2009 por ejemplo, en las jornadas "Intelectuales, democracia y socialismo: callejones sin salida y caminos de apertura", en la que participaron Carmen Bohórquez y Arístides Medina, fundadores del $\mathrm{CNH}$, varios intelectuales chavistas criticaron el hiperliderazgo y la conducción verticalista del movimiento político.

${ }^{4}$ El MBR-200 fue el grupo clandestino creado al interior del ejército venezolano en el año 1983 al cual pertenecía Hugo Chávez, y que fue conocido por la opinión pública en 1992 cuando intentó dar un golpe de Estado al gobierno de Carlos Andrés Pérez.
} 
civiles y otros militares-, sino de distintas corrientes ideológicas, entre ellos hubo discusión y diferencias sobre el rumbo y la orientación del proyecto ${ }^{5}$. Esta diversidad se mantuvo cuando el MBR-20o se transformó en Movimiento V República y posteriormente cuando devino Partido Socialista Unido de Venezuela. En los últimos años y en particular después de la muerte de Hugo Chávez, se ha hablado mucho de la división entre civiles y militares tanto en el gobierno como en el movimiento, suponemos por tanto que estas diferencias pueden también hacerse manifiestas en Memorias de Venezuela, una revista escrita y editada por historiadores civiles.

Por lo tanto, en aras de explorar las relaciones entre el Centro Nacional de Historia y el gobierno desde las producciones del $\mathrm{CNH}$ y no desde el discurso oficial o institucional, nuestro objetivo es analizar la forma como se construye la legitimidad del gobernante a partir de las representaciones del presidente Hugo Chávez incluidas en los 24 números de la revista Memorias de Venezuela. Este ejercicio hace parte de una empresa de más largo aliento con la que se pretende indagar si el $\mathrm{CNH}$ ofrece un relato de nación distinto al que elabora Hugo Chávez a partir de los relatos históricos que incluye en sus discursos y por lo tanto, si hay una disputa desde el $\mathrm{CNH}$ al nacionalismo gubernamental que sea expresión de conflictos en la construcción de hegemonía ${ }^{6}$.

Para alcanzar nuestro objetivo nos apoyamos en la propuesta que hace Roger Chartier sobre los tres niveles que se deben tener en cuenta al analizar representaciones, a saber, el análisis de los textos, el de las materialidades y el de las prácticas (Chartier, 1992, pp. 45-62). Desde allí dividimos el texto en seis apartados. En el primero nos ocupamos de los conceptos que soportan nuestra indagación, a saber, poder, representación y legitimidad. En el segundo nos detendremos en el contexto institucional de producción que es el lugar donde se producen las prácticas que dan origen a las representaciones (Pérez Benavides 2012); dado que ya hemos hecho una corta introducción al contexto, nos centraremos en el Centro Nacional de Historia. En la tercera nos referiremos a la materialidad donde se plasman las representaciones de Hugo Chávez, es decir, a las características de las revistas analizadas. En el cuarto apartado explicaremos las bases del método que usamos para analizar las representaciones. En la quinta parte nos referiremos al análisis de las mismas para luego cerrar con las conclusiones.

\footnotetext{
${ }^{5}$ Sobre la historia del MBR-200, las discusiones y diferencias entre los propios militares y sus acercamientos con civiles, la mayoría de ellos de izquierda, pueden consultarse las distintas entrevistas hechas a los actores del proceso entre ellas Blanco Muñoz (1998; 2003), Ramonet (2013). También los trabajos del historiador Domingo Irwin, como Irwin y Micett (2011).

${ }^{6}$ Este texto se inscribe en el marco del desarrollo del proyecto doctoral titulado "Disputa y negociación del nacionalismo gubernamental en Venezuela durante el Gobierno de Hugo Chávez (19992012)" adelantado en el Doctorado de Ciencias Sociales y Humanas de la Pontificia Universidad Javeriana de Bogotá, Colombia.
} 


\section{La representación del poder}

El poder, que para el filósofo francés Louis Marin es la capacidad de ejercer la fuerza sobre algo o alguien, adquiere su máxima expresión cuando no tiene que ejercerse como fuerza ya que nadie se resiste a él. Esta condición del poder es nombrada por Weber dominación ${ }^{7}$. La dominación puede depender del interés material, de la costumbre, de la afectividad pero lo que hace incuestionable la dominación es la legitimidad, es decir, la creencia en que el poder es legal pues es conforme a alguna ley. Este paso del poder como fuerza a la legitimidad del poder constituye una 'valorización del poder' según Marin y una ‘estabilización de la dominación’ según Weber (Marin, 2009, pp. 135-153).

Marin sostiene que la legitimidad se construye a partir de la representación que permite plasmar el poder en signos y significar la fuerza ${ }^{8}$. Para comprender la operación que efectúa la representación para legitimar el poder se debe partir del concepto de representación definido de dos maneras por el filósofo francés: la representación es “[...] la imagen que nos devuelve como idea y como memoria lo ausente" o "la materialidad que exhibe, expone ante la mirada o presenta públicamente una persona o una cosa" (Marin citado en Chartier,1996, p. 78).

El primer sentido alude a la propiedad transitiva de la representación y a partir de él se puede entender que la representación del poder lo trae a la memoria, hace presente el poder y con él, el temor o el respeto que infunde. El segundo sentido alude a la capacidad reflexiva de la representación, al hecho de que al exhibirse se hace público, prueba su existencia y por lo tanto se legitima. Dice Marin:

Primer efecto del dispositivo representativo, primer poder de la representación: efecto y poder de presencia en lugar de la ausencia y la muerte; segundo efecto, segundo poder: efecto de sujeto, es decir poder de institución, de autorización y de legitimación como resultante del funcionamiento reflejo del dispositivo sobre sí mismo. (Marin, 2009, 137)

Aunque el poder puede mantenerse como amenaza del uso de la fuerza y la dominación como costumbre, el poder y la dominación buscarán siempre legitimarse y para ello usará la imagen, la representación del poder, como lo señala George Balandier:

\footnotetext{
7 Dice Weber: "Debe entenderse por dominación, de acuerdo con la definición ya dada (Cap. I $£ 16$ ), la probabilidad de encontrar obediencia dentro de un grupo determinado para mandatos específicos (o para toda clase de mandatos)" (Weber, 1996, p. 70).

8 "¿Cómo puede la representación llevar a cabo esa transformación? Por un lado, la representación pone la fuerza en signos (así como se pone un barco en el agua), y, por otro significa la fuerza en el discurso de la ley" (Marin, 2009, p. 138)
} 
El objetivo de todo poder es el de no mantenerse ni gracias a la dominación brutal ni basándose en la sola justificación racional. Para ello, no existe ni se conserva sino por la transposición, por la producción de imágenes, por la manipulación de símbolos y su ordenamiento en un cuadro. (Balandier, 1994, p. 18).

Weber establece tres tipos de legitimidad de la dominación: la racional que se funda en la creencia en la legalidad del orden establecido y en los derechos de mando de quienes son llamados por ese orden a ejercer el poder. La legitimidad tradicional que descansa en la creencia cotidiana, en la santidad de las tradiciones que se remontan a tiempos lejanos y que señalan quién debe ejercer el poder. Y finalmente la legitimidad carismática que se funda en la santidad de un héroe o una persona ejemplar que es quien crea el orden legal. A la luz de lo anterior, consideraremos las imágenes producidas por el Centro Nacional de Historia para representar al gobernante de la República Bolivariana de Venezuela, con el fin de analizar la forma como se produce la legitimidad.

\section{El contexto institucional de producción: El Centro Nacional de Historia}

El Centro Nacional de Historia (CNH) se creó mediante decreto presidencial en 2007 y se adscribió al Ministerio del Poder Popular para la Cultura, instituido ese mismo año. Su fundación se produjo después de la reelección de Chávez en el año 2006, en un período que varios autores han señalado como la radicalización del proceso bolivariano pues da inicio a la construcción del socialismo del siglo XXI (Medina, 2007). Sobre el particular hay que señalar que la palabra socialismo solo comenzó a figurar en el discurso de Chávez el año de la reelección.

El CNH tiene entre sus competencias democratizar la historia sacándola de los claustros y del ámbito restringido a los intelectuales. Para tal fin acude a una serie de estrategias, entendidas estas como las prácticas que se llevan a cabo desde el lugar del poder ${ }^{9}$, entre ellas la construcción y administración de museos (El Museo Nacional de Historia, El Museo Nacional de las culturas y los museos bolivarianos) y el financiamiento de libros, discos y revistas en los que se pone a circular un relato histórico con el que se construye el sujeto que requiere la revolución bolivariana ${ }^{10}$.

\footnotetext{
${ }^{9}$ De Certeau define las estrategias de la siguiente manera: "Llamo "estrategia" al cálculo de relaciones de fuerzas que se vuelve posible a partir del momento en que un sujeto de voluntad y de poder es susceptible de aislarse de un "ambiente". La estrategia postula un lugar susceptible de circunscribirse como un lugar propio y luego servir de base a un manejo de sus relaciones con una exterioridad distinta". (De Certeau, 2000, XLIV)

${ }^{10}$ Hacemos extensiva la teoría del relato de Ricoeur al relato histórico. El filósofo francés sostiene que el relato construye la identidad del sujeto, es decir, que el relato de la historia de una comunidad la construye en la medida en que narra su historia. Afirma: "La historia narrada dice el quién de la
} 
En la fundación del Centro Nacional de Historia participaron historiadores e intelectuales de sólida formación académica y de amplia reputación entre ellos Arístides Medina Rubio, Doctor en Historia; Carmen Bohórquez, Doctora en Historia; Pedro Calzadilla, Magíster en Historia; el actual ministro del Poder Popular para la Cultura; y Luis Pellicer, Magíster en Historia, actual director del CNH. Esto intelectuales mantienen una dura polémica con sus pares de la Academia Nacional de Historia (ANH), institución que fue creada en 1888 y de la que tradicionalmente hacían parte aficionados a la historia, pero que hoy reúne a reputados historiadores como Elías Pino Iturrieta, Germán Carrera Damas, María Helena González Deluca e Inés Quintero, quienes se oponen y denuncian la historia oficial que elabora el $\mathrm{CNH}^{11}$.

En palabras del historiador Tomas Straka (2009), los historiadores de la ANH han protagonizado una verdadera 'revolución historiográfica' para oponerse al uso de la historia por parte del Estado y al bolivarianismo como filosofía del Estado venezolano. Esto se ha expresado en la publicación por parte de los cuatro más reputados escritores venezolanos de obras sobre la cuestión bolivariana y de innumerables artículos en los medios de comunicación. Entre los primeros se encuentran El Divino Bolívar ensayo de una religión republicana publicado en 2003 por Elías Pino Iturrieta; la quinta reedición de El Culto a Bolívar, esbozo para un estudio de las ideas en Venezuela y la publicación en 2005 de El bolivarianismo-militarismo, una ideología de reemplazo de Germán Carrera Damas. Guillermo Morón, por su parte, publicó Memorial de Agravios en 2006 y Manuel Caballero, Por qué no soy bolivariano, una reflexión antipatriótica (Straka, 2009).

Este enfrentamiento entre los historiadores de la Academia Nacional de Historia y el gobierno tuvo como un hito importante el retiro que hizo este último de la custodia

acción. La identidad del quien no es pues ella misma más que una identidad narrativa. Sin el recurso de la narración, el problema de la identidad personal está, en efecto, condenado a una antinomia sin solución: o bien se piensa un sujeto idéntico a sí mismo en la diversidad de sus estados, o bien se sostiene [...] que el sujeto no es sino una ilusión sustancialista." (Ricoeur, 2004, p. 28)

${ }^{11}$ Aunque la Academia Nacional de Historia (ANH) se creó en 1888, la profesionalización de la historia tuvo que esperar hasta la salida del poder de Juan Vicente Gómez en 1935. En 1936 se creó el Instituto Pedagógico Nacional, donde por primera vez se ofreció la carrera de Historia. En 1945 se creó la Facultad de Filosofía y Letras de la Universidad Católica de Venezuela y un año después se ofreció la carrera de historia, que en 1955 se abrió también en la Universidad de los Andes. Pero como lo denunció German Carrera Damas en su libro de 1969 El Culto a Bolívar, tanto los historiadores profesionales, es decir, los graduados en historia, como los aficionados, no lograron construir una conciencia histórica fuerte que superara el culto bolivariano que ha funcionado en ese país como una religión cívica. La ANH era el espacio donde se sentaban principalmente los historiadores no profesionales, cultores del Libertador y donde reposaba el archivo de Bolivar. Pero desde la década de 1980, comenzaron a ingresar a esa institución jóvenes historiadores que habían bebido, entre otras, de las fuentes del marxismo y que en palabras de Carrera Damas, ejercían una conciencia crítica frente a la tradicional conciencia histórica bolivariana. Straka (2009) y Carrera Damas (2009). 
en el Archivo de Bolívar y del Archivo de Miranda a la ANH y su posterior ubicación en el Archivo General de la Nación.

\section{Las materialidades: la Revista Memorias de Venezuela}

Memorias de Venezuela es una publicación gratuita que se comenzó a publicar en 2008 con un tiraje normalmente bimestral, superior a los 100.000 ejemplares. Se distribuye a través de Librerías del Sur pero también se puede descargar en versión digital de la página del CNH (http://www.cnh.gob.ve). Al día de hoy se han publicado treinta números, pero restringimos nuestro análisis a las 24 publicaciones hechas hasta el año 2012.

El formato de la revista corresponde a un texto didáctico en el que la información se organiza cronológicamente, por lo que hay secciones dedicadas a la conquista y la colonia, la independencia, el siglo XX y el siglo XXI, entre otras. En algunos casos hay una organización temática en secciones como Historia de la cultura, Lugar de memoria, o Patrimonio. La mayoría de los textos que se incluyen son relatos históricos, complementados siempre con imágenes -no existe una sola página que no tenga imágenes- . Estas imágenes son en su mayoría fotos -hay muy pocas ilustraciones- tomadas de archivos históricos o de las colecciones de los museos, que siempre van acompañadas de la referencia informativa sobre la misma y sobre el archivo en el cual reposan. Este cuidado por las fuentes así como la inclusión al final de cada artículo de un apartado titulado "Para seguir leyendo" en el que se sugiere bibliografía adicional, pretende darle a la publicación un toque académico.

Sin embargo el hecho de que los artículos no incluyan referencias a los archivos o a los autores que soportan la investigación histórica, desvirtúa lo anterior y más bien puede ser interpretado por los lectores como que lo que el texto afirma es absolutamente verdadero e incuestionable, sin depender de las fuentes consultadas o de las perspectivas de análisis. Estos rasgos del formato construyen el tipo de lector de la revista: un público no académico, que busca conocer 'toda la historia de Venezuela', habituado a leer poco -por lo que la imagen le permite hacer menos penosa la lectura- y que no tiene el interés académico y crítico para cuestionar la operación historiográfica que produjo el relato histórico de la revista.

\section{El análisis estructural de contenidos (AEC)}

El método de análisis estructural de contenido (AEC) fue desarrollado a finales de la década de 1970 por Pierre Hiernaux en la Universidad de Lovaina, con el fin de apoyar el estudio de las percepciones y de las representaciones culturales de diversos grupos sociales, es decir, para ser utilizado inicialmente en estudios sociológicos (Hiernaux, 1977). Las bases del método se consignaron en su tesis doctoral que se publicó con el nombre de $L$ 'institution culturelle y desde ese momento hasta hoy, el mismo autor y algunos colegas y sus discípulos se han aplicado al perfeccionamiento, difusión y 
discusión en torno a la forma de aplicar el método (Hiernaux, 1996; Suárez, 2008; Saldarriaga, 2008a; 2008b).

El AEC parte de la distinción entre el contenido de un texto, representación o práctica y el continente del mismo, que alude al modo de expresión. Se ocupa del sentido del texto, de la representación o del acto, dejando de lado el modo de expresión, es decir, el continente. Por esta razón se diferencia de los métodos de análisis del discurso que se ocupan de la forma del mismo (Hiernaux, 2008, p. 69).

El AEC busca explicar la forma como se construye el sentido en un texto, representación o acto poniendo de manifiesto los sistemas de reglas de combinación que usan los actores sociales para construir el sentido. Este sistema de reglas se denomina institución cultural y se define como:

Les système de regles de combinations constitutifs de sens, socialement produits, et socialement eficaces au travers de la manières dont ils informent les perceptions, les pratiques et les modes d'organisation mis en oeuvre par les acteurs sociaux" (Hiernaux, 1977, VII) ${ }^{12}$.

En el desarrollo del método, Hiernaux se apoyó en la Semántica estructural de Greimas donde el lingüista se aplicó a poner las bases de la semántica como la ciencia que estudia la forma en que se construye la significación o el sentido. Greimas a su vez retomó los planteamientos de Ferdinand de Saussure, en particular la idea de que el universo semántico es cerrado y que la lengua es un sistema de signos donde la significación de un signo se produce por su oposición a otro dentro de la totalidad del sistema. Desde esa afirmación "Percibimos diferencias y, gracias a esta percepción el mundo "toma forma" ante nosotros y para nosotros" (Greimas, 1971, p. 28). Greimas planteó que la estructura de la significación o la estructura de sentido consiste en la presencia de dos términos y la relación existente entre ellos. Esta última recibe el nombre de eje semántico. Así por ejemplo, el término 'bajo’ adquiere significación en oposición al término 'alto', sobre la base de un eje semántico que es la verticalidad.

Como es propio de toda ciencia, la semántica requiere también de un lenguaje para describir sus observaciones. En este metalenguaje los términos ‘alto' y ‘bajo' que en lengua natural son llamados 'término objeto' reciben el nombre de lexemas y la relación entre ellos se nombra como eje semántico. El lexema es, junto al fonema, una de las unidades mínimas del discurso (Greimas, 1971, p. 45) . Greimas también propone una notación tomada de la lógica en la que la relación se expresa de la siguiente manera:

\footnotetext{
12 "El sistema de reglas de combinación constitutivas del sentido producido socialmente y que se presentan como socialmente efectivas a través de maneras con las que informan las percepciones, prácticas y modos de organización llevadas a cabo por los actores sociales". (Hiernaux, 1977, VII) (traducción libre)
} 
Alto / está en relación R/ con Bajo donde R es el eje semántico (verticalidad)

Otro de los puntos de partida de Greimas es que en el lenguaje existen distintos niveles que son expresión de las etapas que permiten la construcción de la significación. El nivel de los lexemas o significantes corresponde a las estructuras superficiales. A este nivel subyace el de las estructuras de la manifestación que comprende la gramática semiótica. Siguiendo con el ejemplo, esto quiere decir que 'alto’ y ‘bajo' son lexemas que presuponen otro nivel que es el de la oposición entre los semas verticalidad y horizontalidad. Esto se expresa de la siguiente manera:

Verticalidad / están en relación dimensionalidad/ horizontalidad.

Si se continúa con este procedimiento preguntándose cómo se construye la significación de la dimensionalidad, se llega a un conjunto de relaciones que pueden llamarse sistema sémico, que es el que soporta la significación de términos objetos como alto, bajo, largo, corto, etc., como puede verse en el siguiente ejemplo que tomamos de Greimas. Harán parte de este sistema sémico los semas listados en la primera fila. La presencia $(+)$ o ausencia (-) de esos semas permite la construcción de sentido de los lexemas.

\section{Tabla 1}

\begin{tabular}{|l|l|l|l|l|l|l|l|l|}
\hline Semas & Espacialidad & Dimensionalidad & Verticalidad & Horizontalidad & Perspectividad & Lateralidad \\
\hline \multicolumn{7}{|c|}{ Lexemas } \\
\hline Haut & + & + & + & + & - & - & - \\
\hline Bas & + & + & + & - & - & - \\
\hline Long & + & + & - & + & + & + & - \\
\hline Court & + & + & - & + & + & - & - \\
\hline Large & + & + & - & + & + & - & + \\
\hline étroit & + & + & - & + & + & + \\
\hline vaste & + & - & - & & & & \\
\hline épais & + & - & & & & & \\
\hline
\end{tabular}

Tomado de Greimas, A.J. Semántica Estructural. Madrid: Gredos p. 52

Sobre estos planteamientos aunque usando una notación distinta a la de Greimas, Hiernaux construye su método aplicable no solo al análisis de textos, sino de imágenes o actuaciones. Sostiene Hiernaux que en cualquier producto cultural -texto, imagen etc. - el sentido del término A se construye sobre la oposición a A en el campo de una totalidad, esto se llama estructura de sentido y se expresa de la siguiente forma:

$$
[\mathrm{A} / \sim \mathrm{A}] \approx \text { la totalidad }
$$

En este ejemplo A es un código objeto [objeto], pero la lectura del texto hace emerger códigos calificativos [calificativos] atribuibles a cada una de las partes del código disyuntivo, que permite armar grafos para entender la forma como se produce el sentido. Así podría ocurrir que: 
- Código objeto $[\mathrm{A} / \sim \mathrm{A}] \approx$ la totalidad

- Código calificativo 1 [bueno/ malo] $\approx$ moralidad

- Código calificativo 2 [traicionado / tratado con fidelidad] lealtad

El grafo que expresa la forma como se construye el sentido del término A o el sistema de sentido es:

Tabla 2

\begin{tabular}{|l|l|l|l|l|}
\hline $\mathrm{A}$ & $/$ & $\sim \mathrm{A}$ & $\approx$ & Eje semántico \\
\hline $\mathrm{I}$ & & $\mathrm{I}$ & & \\
\hline bueno & $/$ & malo & $\approx$ & moralidad \\
\hline $\mathrm{I}$ & & $\mathrm{I}$ & & \\
\hline traicionado & $/$ & tratado con lealtad & $\approx$ & fidelidad \\
\hline
\end{tabular}

Si se aplica este análisis a varios productos culturales de un grupo social, es posible encontrar un sistema de códigos disyuntivos jerarquizados, al modo del sistema sémico de espacialidad que tomamos de Greimas, que le permite a ese grupo crear sentido alrededor de elementos de una determinada realidad. Esa organización jerarquizada recibe el nombre de orden categorial en Hiernaux (Hiernaux, 1977, p. 67).

El segundo nivel al que se accede aplicando el principio de que el sentido se construye por oposición frente a una totalidad es el que Hiernaux llama orden universal (Hiernaux, 1977, p. 67). Este es el que explica la percepción global de lo real pues tiene que ver con la forma como se organiza el espacio, el tiempo, los actores, las acciones y los objetos.

El tercer nivel de la institución cultural es el orden actancial que recoge la forma como se construye el sentido sobre el campo de la acción. Para extraer la estructura de sentido en ese nivel, Hiernaux se apoya en el esquema actancial de Greimas (Greimas, 1971).

En este artículo nos referiremos solamente a la construcción del sentido sobre un actor del orden universal y a la relación de esto con la construcción de la legitimidad.

\section{Las representaciones de Hugo Chávez}

En las 24 revistas de Memorias de Venezuela se incluyen 22 representaciones de Hugo Chávez que agrupamos sobre la base de los elementos presentes en ellas.

Tabla 3

\begin{tabular}{|l|l|l|l|}
\hline \multicolumn{4}{|c|}{ Tipos de representaciones de Hugo Chávez Frías } \\
\hline Atuendo & \multicolumn{1}{|c|}{ Otros elementos } & $\begin{array}{c}\text { No. de } \\
\text { representaciones }\end{array}$ & \multicolumn{1}{|c|}{ Fuente: Revista } \\
\hline \multirow{2}{*}{ De civil } & Con símbolos de legitimidad & 8 & $\# 6, \# 4, \# 24, \# 8, \# 17$ \\
\cline { 2 - 4 } & Entre el pueblo & 6 & $\# 8, \# 12 \# 17 \# 6$ y \#23 \\
\hline \multirow{2}{*}{$\begin{array}{l}\text { Con uniforme } \\
\text { militar }\end{array}$} & El 4 de febrero de 1992 & 5 & $\# 6, \# 21, \# 24, \# 8, \# 12$ \\
\cline { 2 - 4 } & Con otros militares del MBR-200 & 1 & $\# 24$ \\
\cline { 2 - 4 } & Con símbolos de legitimidad & 1 & $\# 8$ \\
\cline { 2 - 4 } & Orando & 1 & $\# 8$ \\
\hline
\end{tabular}


En catorce representaciones Hugo Chávez aparece en traje civil. En ocho de ellas ostenta símbolos de legitimidad legal-racional como son la banda presidencial y la constitución.

\section{Fotografía 1}

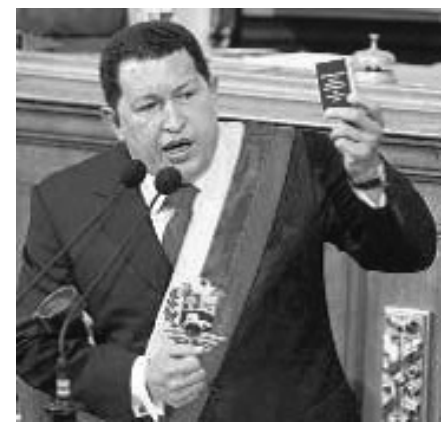

Entre estas ocho representaciones hay dos que se repiten y que muestran el día de la juramentación en la que el nuevo presidente aparece acompañado de su antecesor Rafael Caldera, el fundador de COPEI, uno de los partidos tradicionales de Venezuela. La disposición de los elementos en las imágenes, a saber, Chávez adelante, erguido, joven y asumiendo el compromiso de conducir el país, contrasta con la imagen en segundo plano del ex presidente, viejo y encorvado. En la Revista \# 6 el pie de foto es el siguiente: “A finales del siglo XX Venezuela entraría en una nueva fase política y social. El fin de la hegemonía puntofijista se vería expresada en la elección de Hugo Rafael Chávez Frías como presidente de la Republica”.

\section{Fotografía 2}

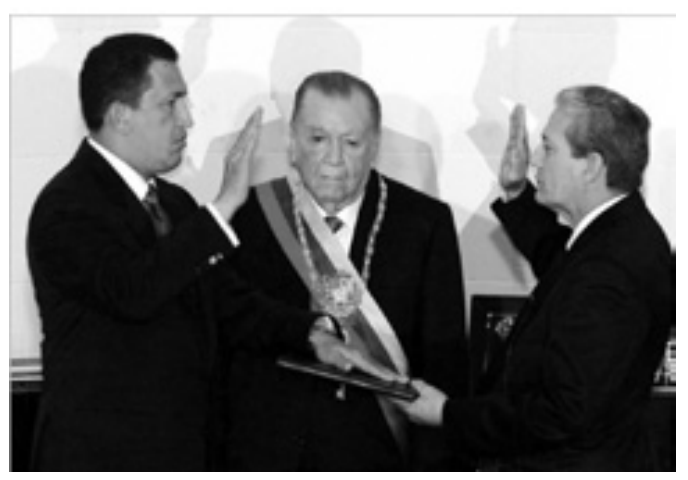

El AEC de la foto muestra que el sentido de Chávez en esa representación se construye en oposición a Caldera. Los actores se diferencian en términos de su posición, su actitud, los momentos políticos que representan y lo que hemos llamado 'momentos 
de lo no eterno', pues solo lo no eterno nace y envejece. Esa estructura de sentido se recoge en el siguiente grafo:

Tabla 4

\begin{tabular}{|l|l|l|l|l|}
\hline \multicolumn{7}{|c|}{ Grafo: Hugo Chávez y Rafael Caldera. } \\
\hline Chávez & I & Caldera & $\approx$ & Gobernantes \\
\hline I & & I & & \\
\hline Adelante & $/$ & Atrás & $\approx$ & Posición \\
\hline I & & I & & \\
\hline Erguido & $/$ & Encorvado & $\approx$ & Actitud \\
\hline I & & I & & $\begin{array}{l}\text { Momentos de lo } \\
\text { no eterno }\end{array}$ \\
\hline Joven & $/$ & Viejo & $\approx$ & $\begin{array}{l}\text { Momentos } \\
\text { políticos }\end{array}$ \\
\hline I & & I & & \\
\hline $\begin{array}{l}\text { Nueva fase } \\
\text { política }\end{array}$ & $/$ & Puntofijismo & $\approx$ & \\
\hline
\end{tabular}

En las otras seis representaciones en que Chávez aparece de civil, o bien tiene una mano alzada en señal de victoria o bien extiende los brazos hacia la gente del pueblo que también extiende las suyas. En las Revistas \# 17 y \# 6 estas representaciones se ponen continuas a las de los políticos tradicionales que aparecen en espacios privados abrazándose a ellos mismos como puede verse en las siguientes imágenes.

\section{Tabla 5}

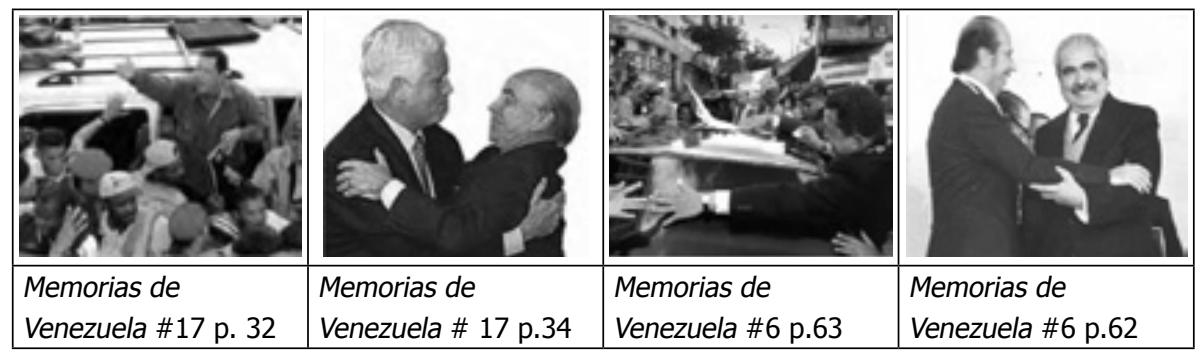

Las representaciones de la posesión y las cuatro representaciones arriba incluidas hacen parte de la misma isotopía ${ }^{13}$, es decir, de un lugar estructural común en el que el sentido adquiere coherencia. En este caso la isotopía puede ser nombrada como

\footnotetext{
${ }^{13}$ La isotopía es el lugar estructural donde se encuentran distintas estructuras de sentido y desde el cual se les da coherencia. Puede entenderse el concepto si se supone que 'pan', 'alimentos', 'comer' son estructuras de significación que forman una realidad homogénea, una isotopía que podemos llamar 'isotopía alimentaria'. El ejemplo es tomado del Equipo "Cahier Evangile" (Equipo Cahier Evangile, 1980, p. 23).
} 
"Chávez y los gobernantes del puntofijismo" y se puede resumir en el siguiente grafo que condensa el análisis:

\section{Tabla 6}

\begin{tabular}{|l|l|l|l|l|}
\hline \multicolumn{5}{|c|}{ Grafo condensación : Hugo Chávez y los gobernantes del puntofijismo } \\
\hline Hugo Chávez & $/$ & $\begin{array}{l}\text { Políticos } \\
\text { tradicionales }\end{array}$ & $\approx$ & Gobernantes \\
\hline I & & I & & \\
\hline público & $/$ & privado & $\approx$ & Espacio \\
\hline I & & I & & Orientación \\
\hline Hacia el pueblo & $/$ & $\begin{array}{l}\text { Hacia ellos } \\
\text { mismos }\end{array}$ & $\approx$ & $\begin{array}{l}\text { Momentos de lo } \\
\text { no eterno }\end{array}$ \\
\hline I & & I & & \\
\hline nuevo & $/$ & viejo & $\approx$ & \\
\hline
\end{tabular}

Lo que la isotopía pone de manifiesto es que el sentido de Chávez en tanto que gobernante legítimo se construye en oposición a los políticos tradicionales. Hugo Chávez representa los nuevos tiempos que son los de la democracia -un régimen que se da en el espacio público y que favorece al pueblo-. Los políticos tradicionales se asocian a un gobierno oligárquico - un gobierno de pocos en el espacio privado al que entran pocos. Podemos afirmar que las catorce representaciones de Hugo Chávez en traje civil pretenden representar el poder para legitimarlo y lo legitiman como legal-racional a través de la introducción en las representaciones de elementos como la constitución y la banda presidencial. Esto se refuerza desde la oposición del gobernante a las oligarquías, lo que construye su sentido como un gobernante democrático.

En otras dos representaciones, una de ellas con traje de civil y otra con traje militar, aparece Hugo Chávez en primer plano acompañado en segundo plano de la foto de Simón Bolívar (CNH, \#8 p. 54; \#17 p. 34) . Estas representaciones establecen una continuidad entre el pasado y el presente por lo que pueden ser interpretadas como un intento de reforzar la legitimidad legal-racional con la legitimidad tradicional, fundada en la sacralización de la tradición. En el pasado y en particular en la representación de El Libertador se encuentra, según Carrera Damas, la unidad nacional que se constituyó para alcanzar la independencia, la reivindicación del orden, pues Bolívar fue el fundador de la III República y luego prácticamente a través de su culto ${ }^{14}$, la IV República se

${ }^{14}$ El culto a Bolívar se inició en 1842 con la repatriación de sus restos por parte del gobierno de José Antonio Páez. Durante los gobiernos de Antonio Guzmán Blanco se celebraron lo que Frédérique Langue nombró como "cuatro hiperbólicas glorificaciones heroizantes" a saber: el paseo triunfal y la exhibición de sus pertenencias con motivo de las Fiestas de la Paz (28 de octubre de 1872), la inauguración de su estatua ecuestre en Caracas (7 de noviembre de 1874), el traslado de sus 
le consagra a él, una fuente de inspiración política y un factor de superación nacional pues, al no cumplirse las promesas de la independencia, estas se disponen en un futuro permanente al invocarse siempre la imagen y el pensamiento del Padre fundador de la Patria. Según la visión del historiador, el futuro inspirado en el pasado, estaría siempre en vías de realización (Carrera Damas, 2008).

El otro tipo de representación que aparece con más frecuencia (cinco veces) es la foto de Hugo Chávez tomada en la mañana del 4 de febrero de 1992 cuando, habiendo fracasado el golpe militar, torpemente el Presidente Carlos Andrés Pérez le permitió hablar por televisión para invitar a los insurrectos a dejar las armas. Fue una alocución de un minuto y 20 segundos en la que el hasta entonces desconocido Comandante Chávez apareció vestido con su uniforme de paracaidista, invitando a la reflexión y a evitar derramamientos de sangre. Una intervención mediática en la que asumió la responsabilidad del golpe ante sus compañeros y ante el país. Chávez anunciaba que "por ahora los objetivos que planteamos no fueron logrados" y que seguramente vendrían para Venezuela tiempos mejores ${ }^{15}$. Esta primera aparición pública ha sido muy estudiada pues causó un impacto muy favorable en la opinión pública venezolana: un desconocido militar, por sus rasgos físicos de evidente extracción popular, valiente y seguro, anunció con el 'por ahora' su regreso. Según Eleonora Bruzual, este fue el más corto, el más barato y el más efectivo anuncio político de la historia de Venezuela pues el 'por ahora' creó una expectativa de regreso que se concretó y que fue frase de campaña en el año 1998 (Bruzual 1999, pp. 105-113).

Pero esta aparición también fue el inicio de la heroización de la figura de Hugo Chávez gracias a sus rasgos de militar valiente en una sociedad que tiene una tradición de culto al hombre de armas (Hébrard, 2006) pero también porque el interés de la opinión pública por saber quiénes eran esos golpistas motivó a académicos y a periodistas a indagar sobre ellos. Los artículos y los libros que salieron de esas investigaciones ${ }^{16}$ permiten ver que el Movimiento Bolivariano Revolucionario 200 pretendía construir una representación de Chávez caracterizada por ser un hombre del pueblo, con un antepasado heroico -su abuelo Maisanta luchó por la reforma agraria a inicios del siglo

cenizas al Panteón Nacional (28 de octubre de 1876) y el Centenario de su nacimiento (1883) (Langue, 2011). Durante el gobierno de Juan Vicente Gómez (1908-1935) en el que culminó el proceso de formación nacional, se conmemoraron los 100 años de la muerte de El Libertador, ocasión que aprovechó el régimen para asociar su logro de cancelar la deuda externa con la idea de independencia frente a las potencias. Por su parte, el gobierno de Eleázar López Contreras (1935-1941) inventó las Cívicas Bolivarianas, organizaciones políticas para movilizar electores y Luis Herrera Campins en 1983, en el marco de la celebración del bicentenario del natalicio de Bolívar, le ofrendó el Metro de Caracas y los Juegos Panamericanos.

${ }^{15}$ La alocución puede verse en Youtube en el siguiente enlace: http://www.youtube.com/ watch?v=OiIyGehNiUM

${ }^{16}$ Entre ellos Blanco Muñoz, (1998) y Zago, A. (1998). 
XX- que se enfrentaba a las fuerzas del mal encarnadas en las oligarquías de la Cuarta República y que quería rescatar la tradición heroica venezolana. Así que la inclusión en la revista de la representación de Chávez el día del golpe no solo pretende revivir los sentimientos suscitados por su primera aparición en televisión, sino que busca contribuir a tal heorización.

Una de estas representaciones de Chávez el día del golpe se incluye a media página en la sección Efemérides, es decir, lo que hay que conmemorar. Allí aparece acompañada del texto "El líder del movimiento, Hugo Chávez, asumió ante el país la responsabilidad de lo ocurrido" (CNH, \#12 p. 3). Otra de las representaciones es portada en página completa de Memorias de Venezuela \#24 dedicada al “4-f. La revolución de febrero”. En realidad se trata de una representación de la representación de Hugo Chávez el día del fracasado golpe, cargada por el pueblo al modo como se llevan las imágenes religiosas en las procesiones.

\section{Fotografía 3}

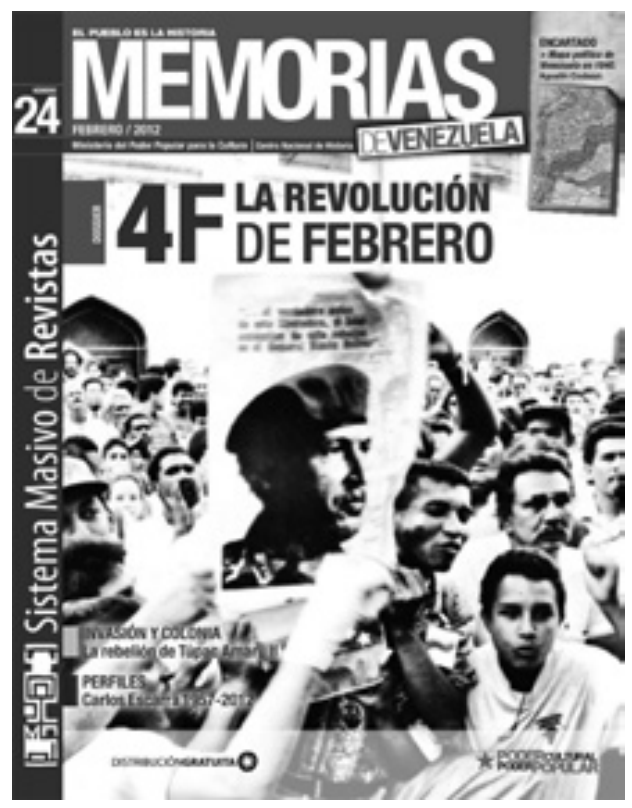

Portada de la Revista Memorias de Venezuela \#24

Esta es tal vez una de las representaciones más poderosas incluida en la revista no solo por su tamaño, por ser portada y porque el pueblo exhibe la aceptación de la dominación, sino porque en un texto muy borroso, encima de la boina de Chávez, se puede leer lo siguiente: “el verdadero autor de esta rebelión es el General Simón Bolívar”. Este frase refuerza la legitimidad carismática que emana del heroísmo con la legitimidad tradicional que proviene de Bolívar pues plantea que a través de Chávez, actúa el héroe nacional 
alrededor de cuyo culto se construyó la nación. Por otra parte el análisis estructural permite ver que el sentido de Hugo Chávez se construye en oposición a pueblo en términos de número y de posición: Chávez es uno y está arriba y adelante, es pues el líder y el que domina porque se encuentra por encima de los muchos que lo cargan y que lo siguen.

Los rasgos heroicos de Chávez se perfilan en otros apartes de la revista. Así, por ejemplo, en la misma revista \#24 se incluye un dossier titulado “4-f: la revolución de febrero" que engaña al lector sobre la naturaleza de los hechos acaecidos ese día pues los califica como 'revolución', siendo que tal término indica un cambio estructural, cosa que no se produjo porque el golpe falló. También se sostiene en el texto que el 4-f fue una "rebelión cívico-militar", cuando justamente una de las causas del fracaso del golpe fue que los militares ni buscaron ni contaron con el apoyo popular. Esta combinación entre el relato y la representación de Hugo Chávez pretenden construirlo como un héroe revolucionario (CNH, \#24 p. 22 y ss.).

Un nuevo rasgo del héroe se perfila en la Revista \#8 dedicada al golpe que se produjo el 11 de abril de 2002. Ese día los partidos tradicionales, la Federación de empresarios y algunos grupos económicos con apoyo de un sector de militares, depusieron del poder a Chávez por dos días. La revista incluye una representación de Chávez tras su retorno al poder, con la cabeza baja, rezando, como agradeciendo a Dios. Esta representación que va acompañada del texto "Con un crucifijo en la mano Chávez pasaría la historia como el primer vencedor que, luego de violenta disputa por el poder, no avasalla al vencido inmediatamente después del desenlace de la contienda”, sugiere que es un héroe compasivo pero además, el uso del pospretérito - 'pasaría'-indica que se escribe la historia del presente como si ya esta hubiese concluido, dado que la revista se escribe cuando Chávez está aún en el poder (CNH, \#8, p. 59).

En síntesis, las representaciones de Hugo Chávez el 4 de febrero que evocan el carácter heroico que percibió la gente ese día y que la revista refuerza con los textos y con la forma como se dispone la representación, pretenden construir una legitimidad carismática que es la que descansa en las condiciones excepcionales que tiene un caudillo, en este caso, el heroísmo y la compasión aún frente a quienes lo depusieron del poder.

\section{Para concluir}

Las representaciones de Hugo Chávez en Memorias de Venezuela hacen parte de una estrategia para construir la legitimidad del Presidente desde tres fuentes: la ley, la tradición y el carisma. La legitimidad legal racional se construye desde la inclusión en las representaciones de elementos que, como la constitución y la banda presidencial, apuntan a que su ascenso al poder se hizo respetando la ley. La legitimidad tradicional por su parte, se logra estableciendo continuidad entre el proyecto, la figura de Simón Bolívar y la de Hugo Chávez. Finalmente, la legitimidad carismática apoyada en menos representaciones que la primera, se consigue a través del uso de la representación de 
Chávez el día del golpe del 4 de febrero de 1992 y a partir de los textos que acompañan tales representaciones. No obstante, aunque pareciera ser que la revista busca darle mayor peso al primer tipo de legitimidad pues quince de las veintidós representaciones aluden a ella, la fuerza de una representación como la comentada de la portada de la revista \# 12 por lo menos equipara la importancia de la legitimidad legal racional y de la carismática.

A partir de lo anterior se puede concluir que por lo menos desde la representación del poder, el Centro Nacional de Historia buscar legitimar al gobernante y aunque lo hace destacando el origen legal y racional del poder, como es lo propio de las democracias modernas, también refuerza su carisma y su vínculo con la tradición. Llama también la atención la inclusión de imprecisiones históricas, en particular las relativas al carácter del 4 de febrero, que se califica como ‘revolución' con participación ‘cívica y militar'. Esto lanza una sombra de duda sobre la representancia ${ }^{17}$ de los textos incluidos en la revista, es decir, sobre su capacidad para representar el pasado y obra como argumento a favor de los reclamos de los historiadores de la Academia Nacional de Historia que se quejan de la tergiversación de la historia por parte del Gobierno y de sus allegados.

\section{Referencias}

Abrams, P. (1988). Notes on the difficulty of stuying the state. Journal of historical sociology, 1(1), 58-89.

Agüero, F. (1993). Las fuerzas armadas y el debilitamiento de la democracia en Venezuela. Revista Fuerzas armadas y sociedad, VIII,(2), XXXX.

Almarza, A. (2011). Dos siglos de historias mal contadas. En Quintero, I. El relato invariable. Independencia, mito y nación (pp. 125-154). Caracas: Alfa, 2011.

Alonso, A. M. (29006). Políticas de espacio, tiempo y sustancia: formación del estado, nacionalismo y etnicidad. En Camus, M. Las ideas detrás de la etinicidad. Una selección de textos para el debate (pp. 159-195). Antigua: Colección Por qué estamos como estamos.

Alvarez, A. E. La crisis de la hegemonía de los partidos polìticos venezolanos. En El sistema político venezolano: crisis y transformaciones (pp. 131-152). Caracas: Universidad Central de Venezuela.

\footnotetext{
17 "La investigación en historia reemplaza el recordar mnemónico; abarca, por lo tanto, el conjunto de las operaciones historiográficas en el largo trayecto desplegado de la fase documental a la fase escrituraria. Al final de este recorrido es cuando se plantea en toda su problemática el tema de la representación por los historiadores, a la cual propongo desde ya darle el nombre de representancia, para destacar su aspecto militante e inconcluso, en vez de y en lugar del esquivo reconocimiento mnemónico." (Ricoeur, 2010)
} 
Anderson, B. (1993). Comunidades imaginadas : reflexiones sobre el origen y la difusión del nacionalismo. México: Fondo de Cultura Económica.

Angosto, L. F. (2008). Pueblos indígenas, guaicaipurismo y socialismo del siglo XXI en Venezuela. Revista Antropológica, LII(10), 9-33.

Angosto, L. F. (2010). Pueblos indígenas, multiculturalismo y la nueva geometría del poder. Cuadernos del Cendes, 27, 97-132.

Aponte Moreno, M. (2008). Metaphors in Hugo Chávez's political discourse: conceptualizing nation, revolution and opposition. Tesis no publicada para optar al grado de doctor en Filosofía en el Graduate Faculty in Hispanic and luso- brazilian literature and languages.

Arenas, N. y Gómez Calcaño, L. (2011). Los círculos bolivarianos. El mito de la unidad del pueblo. En Ramos, J.A. (Comp.) La revolución bolivariana. El pasado de una ilusión (pp. 219-258). Caracas: La hoja del norte.

Aristóteles. (1973). Poética. Madrid: Editorial Aguillar.

Arlotta, P. et al. (2012). Análisis crítico del tercer ensayo de Anatomía de la crítica de Northrop Frye. Scribd. Disponible en: http://es.scribd.com/doc/63584902/ Monografia-de-Frye.

Ashcroft, B. et al. (1998). Key concepts in post-colonial studies. London: Routledge.

Bal, Mi. (1990). Teoría de la narrativa (una introducción a la narratología). Madrid: Cátedra.

Balandier, G. (1994). El poder en escenas. De la representación del poder al poder de la representación. Barcelona: Paidós.

Balibar, E. (1991a). ¿Existe el neorracismo? En Balibar y Wallerstein Raza, nación y clase (pp. 31-47). Madrid: Iepala textos.

Balibar, E. (1991b). Racismo y nacionalismo. En Balibar y Wallerstein Raza, nación y clase (pp. 63-111). Madrid: Iepala textos.

Balibar, E. (1991c). La forma nación: historia e ideología. En Balibar y Wallerstein Raza, nación y clase (pp. 135-168). Madrid: Iepala textos.

Bejarano, A. M. (2011). Democracias precarias. Trayectorias políticas divergentes en Colombia y Venezuela. Bogota: Universidad de los Andes. Facultad de Ciencias Sociales.

Beristáin, H. (1995). Diccionario de Retórica y Poética. Buenos Aires: Editorial Porrúa. 
Bhabha, H. (2000). Narrando la nación. En Fernández, A. (Comp.) La invención de la nación lecturas de la identidad de Herder a Homi Bhabha (pp. 211-219). Buenos Aires: Manantial.

Bhabha, Hi. (2002). Diseminación: tiempo, narrativa y márgenes de la nación moderna. En Von der Walde, E. (Ed.). Miradas anglosajonas al debate sobre la nación (pp. 39-74). Bogotá: Imprenta nacional.

Blanco Muñoz, A. (1998). Habla el comandante. Caracas: Universidad Central de Venezuela.

Bolivar, I. (2001). La construcción de la nación y la transformación de lo político. En Bolívar, I., Medina, G. y Ladrón de Guevara, A. Nación y sociedad contemporánea (pp. 9-53). Bogotá: Ministerio de Cultura.

Bolivar, S. (1815). Carta de Jamaica. Caracas: Ministerio del Poder Popular para la Comunicación y la Información.

Britto García, L. (1989). El poder sin la máscara. De la concertación populista a la explosión social. Caracas: Alfadil Ediciones.

Bruzual, E. (1999). Chávez: encantador de masas. En Uzcátegui, J. L. Chávez: Mago de las emociones (pp. 105-113). Caracas: LithoPolar.

Buxton, J. (2005). Venezuela's contemporary political crisis in historical context. Bulletin of Latin American Research, 328-347.

Calzadilla, P. (2004). Las ceremonias bolivarianas y la determinación de los objetos de la memoria nacional en Venezuela. Tierra firme, 22(86), 211-228.

Capriles, C. (2006, enero-junio) La enciclopedia del chavismo o hacia una teología del populismo. Revista venezolana de Ciencia Política, 29, 73-92.

Carrera Damas, G. (1983). Simón Bolívar, el culto heróico y la nación. The hispanic american historical review, 67(1), 107-145.

Carrrera Damas, G. (1989). Culto a Bolivar. Esbozo para un estudio de las historia de las ideas. Caracas: Grijalbo.

Carrera Damas, G. (1998). La larga marcha de la sociedad venezolana hacia la democracia. Caracas: Contraloría General de la República.

Carrera Damas, G. (2005a). El bolivarianismo-militarismo. Una ideología de reemplazo. Caracas: Ala de Cuervo.

Carrera Damas, G. (2005b).Achicar la sentina de la historiografía venezolana. Conferencia inaugural de la cátedra José de Ovidedo y Baños. Escuela de Historia. Universidad Central de Venezuela. Caracas. 
Carrera Damas, G. (2008). El culto a Bolívar. Caracas: Lauki editores.

Castells, M. (2005). La era de la información. economía, sociedad y cultura. tomo III. Madrid : Alianza editorial.

Castro-Gomez, S. (1999). Epistemologías coloniales, saberes latinoamericanos: el proyecto teórico de los estudios subalternos. En De Toro et al. La postcolonialidad en Latinoamérica en la era de la globalización. ¿cambio de paradigma en el pensamiento teórico- cultural latinoamericano? (pp. 79-10o). Madrid: Iberoamericana.

Castro- Gómez, S. (2005). La hybris del punto cero: ciencia, raza e ilustración en la Nueva Granada (1750-1816). Bogotá: Universidad Javeriana.

Castro Leiva, L. (1991). De la patria boba a la teología bolivariana. Ensayos de historia intelectual. Caracas: Monte Avila Editores.

Castro-Urioste, J. (1994) La imagen de nación en Doña Bárbara. Revista de crítica literaria (37), 127-139.

Cavarozzi, M. (1996). El capitalismo político tardio y su crisis en América Latina. Rosario: Homo Sapiens.

Chartier, R. (1992). El mundo como representación. Barcelona: Gedisa.

Chartier, R. (1996). Poderes y límites de la representación. Marin, el discurso y la imagen. En Escribir las prácticas. Foucault, De Certeau, Marin, (pp. 71-99). Buenos Aires: Manantial.

Chatterjee, P. (1995). Nationalism as a problem. En Ashcroft et al. The postcolonial studies reader (pp. 164-167). London: Routledge.

Chatterjee, P. (1996). Comunidad imaginada ¿Por quien? (traducción). En Balakrishnan, G. Mapping the nation (pp. 214-223). London: Verso.

Chatterjee, P. (2008). La nación en tiempo heterogéneo y otros estudios subalternos. Buenos Aires: Siglo XXI Editores.

Chávez, H.(1992). Un brazalete tricolor. Caracas: Vadell hermanos editores.

Chávez, H. (2002, abril 14). Alocución a la nación al retornar al poder. Disponible en: http://www.analitica.com/bitblioteca/hchavez/vuelta_al_poder.asp

Chavez, H. y equipo asesor. (1998). Una revolución democrática (programa de gobierno). Disponible en http://www.analitica.com/bitblioteca/hchavez/programa.asp.

Chirinos, A. y Molero de Cabeza, L. (2007, enero-junio). la imagen del yo y del otro: construcción de identidades en los discursos de toma de posesión de los presidentes de Venezuela y Brasil. Boletín de Lingüística, XIX(27), 70-93. 
Chumaceiro, I. (2003). El discurso de Hugo Chávez: Bolívar como estrategia para dividir a los venezolanos. Boletín de lingüística, 2O, 22-42.

Chumaceiro, I. (2004). Las metáforas políticas en el discurso de dos líderes venezolanos. Hugo Chávez y Enrique Mendoza. Revista Latinoamericana de Estudio del discurso, 91-113.

Chumaceiro, I. (2009). El discurso de Hugo Chávez. Del poder de la seducción a la confrontación como estrategia. En Ramos Pismataro y Romero (Eds.). Hugo Chávez: una década en el poder (pp. 193-217). Bogotá: Universidad del Rosario.

$\mathrm{CNH}$, Centro Nacional de Historia (2008, agosto). Memorias de Venezuela. \#4. Caracas: Ministerio del Poder Popular para la Cultura.

$\mathrm{CNH}$, Centro Nacional de Historia (2008, noviembre-diciembre). Memorias de Venezuela. \#6. Caracas: Ministerio del Poder Popular para la Cultura.

$\mathrm{CNH}$, Centro Nacional de Historia (2009, abril). Memorias de Venezuela. \#8. Caracas: Ministerio del Poder Popular para la Cultura.

$\mathrm{CNH}$, Centro Nacional de Historia (2009, diciembre). Memorias de Venezuela. \#15. Caracas: Ministerio del Poder Popular para la Cultura.

$\mathrm{CNH}$, Centro Nacional de Historia (2010, enero). Memorias de Venezuela. \#12. Caracas: Ministerio del Poder Popular para la Cultura.

$\mathrm{CNH}$, Centro Nacional de Historia (2010, octubre). Memorias de Venezuela. \#16. Caracas: Ministerio del Poder Popular para la Cultura.

CNH - Centro Nacional de Historia. (2011). La revolución de independencia 1795-1830. Caracas: Ministerio del poder popular para la comunicación y la información.

CNH, Centro Nacional de Historia (2011, agosto). Memorias de Venezuela. \#21. Caracas: Ministerio del Poder Popular para la Cultura.

CNH, Centro Nacional de Historia (2011, diciembre). Memorias de Venezuela. \#23. Caracas: Ministerio del Poder Popular para la Cultura.

$\mathrm{CNH}$, Centro Nacional de Historia (2012, febrero). Memorias de Venezuela. \#24. Caracas: Ministerio del Poder Popular para la Cultura.

Cohen, I. (1993). A New Latin American and Caribbean Nationalism. Annals of the American Academy of Political and Social Science. Free Trade in the Western Hemisphere, 526, 36-46.

Collier, D. y Berins, R. (2002). Shaping the political arena. Critical junctures, the labor movement, and regime dynamics in Latin America. Indiana: Notre Dame. 
Colom González, F. (1998). Razones de identidad. Pluralismo cultural e integración política. Barcelona: Anthropos.

Colom González, F. (2003). La imaginación nacional en América Latina. Historia Mexicana, LIII(2), 313-339.

Colom González, F. (2005). Lenguaje políticos y construcción de identidades. Coherencia, 2(2), 39-54.

Colom González, F. (2006). Narrar la nación. ARBOR Ciencia, Pensamiento y Cultura, (722), $741-750$

Coronil, F. (1997). The magical state. Nature, Money and Modernity in Venezuela. Chicago: University of Chicago Press.

Coronil, F. y Skurski, J. (1991). Dismembering the nation: the semantics of political violence in Venezuela. Comparative studies in society and history, 33(2), 288-337.

Dávila, L. R. (2001). Dictadura y democracia en Venezuela. Discurso y mito del gendarme necesario. En Ramos J. A. (Comp.). La Revolución bolivariana. El pasado de una ilusión (pp. 19-54). Caracas: La hoja del norte.

Dávila, L. R. (2005). Independencia e insuficiencia en la construcción de la nación venezolana. En Colom, F. Relatos de nación. La construcción de las identidades nacionales en el mundo hispánico (pp. 275-310). Madrid: Editorial Iberoamericana.

Dávila, L. R. (2006). Los momentos fundacionales del imaginario democrático venezolano. En Carrera, D. et al. Los mitos políticos en la sociedades andinas (pp.126162). Caracas: Equinoccio.

De Certeau, M. (2000). El oficio de la historia. La invención de lo cotidiano. Artes del hacer. México, D.F.: Universidad Iberoamericana.

De Laire, F. (2008). El análisis estructural de Hiernaux. Una colonización sociológica de la lingüistica. En Suárez, H. J. (Coord.). El sentido y el método. Sociología de la cultura y análisis de contenido (pp. 23-39). México, D.F.: UNAM.

De Saussure, F. (1945). Curso de lingüistica general. Buenos Aires: Editoral Losada.

De Toro, A. (1999). La postcolonialidad en Latinoamérica en la era de la globalización. ¿cambio de paradigma en el pensamiento teórico-cultural latinoamericano? En De Toro, et al. (Eds.). El debate de la postocoloalidad en Latinoamérica (pp. 31-78). Madrid: Iberoamérica.

Delannoi, G. (1993). La teoría de la nación y sus ambivalencias. En Delannoi, G. y Taguieff, J. P. (Comps.). Teorias del nacionalismo (pp. 9-16). Barcelona: Paidos. 
Domingo, I. (2009). Relaciones civiles y militares en Venezuela. En Ramos Pismataro y Romero (Coords.). Hugo Chávez: una década en el poder (pp. 695-751) Bogotá: Universidad del Rosario.

Domingo, I. y Buttó, L.A. (2006). “Bolivarianismos” y Fuerza Armada en Venezuela. Revista Nuevo Mundo, Mundos Nuevos (6), Disponible en: http://nuevomundo. revues.org/1320

Domingo, I. y Castillo, H. (2008). El general en jefe Raúl Isaías Baduel: testimonio y crítica del tiempo presente criollo. Nuevo Mundo, Mundos Nuevos, o8.

Eastwood, J. (2006). The rise of nationalism in Venezuela. Gainesville: University Press of Florida.

Eastwood, J. (2007). Contextualizando a Chávez: el nacionalismo venezolano contemporáneo desde una perspectiva histórica. Revista Mexicana de sociología, 69(4), 605-639.

Ellner, S. (2001). Hugo Chávez: Radical populist or neopopulist. Paper prepared for delivery at the 2001 meeting of the Latin American. Washington.

Ellner, S. (2004). Hugo Chávez y Alberto Fujimori: análisis comparativo de dos variantes de populismo. Revista Venezolana de Economía y ciencias sociales, 13-37.

Equipo Cahier Evangile (1980). Iniciación en el análisis estructural de relatos. Navarra: Verbo divino.

Fanon, F. (2007). Los condenados de la tierra. Buenos Aires: Talleres gráficos Kolectivo.

Farías de Estany, J. y Molero de la Cabeza, L. (2009). Propulsoras y propulsores: construcción de la identidad y la alteridad de género en el discurso. Espacio Abierto, 18(2). 367-387.

Ferrater, J. (1994). Diccionario de Filosofía. Barcelona: Ariel.

Geertz, C. (2003). La interpretación de las culturas. Barcelona: Gedisa.

Gellner, E. (1988). Naciones y nacionalismos. Madrid: Alianza Editorial.

Giroud, J. C. y Panier, L. (1988). Semiótica. Navarra: Verbo divino.

González Deluca, M. H. (2005). Historia, usos, mitos, demonios y magia revolucionaria. Revista Venezolana de Economía y Ciencias Sociales, 159-186.

González Oquendo, L. Bolívar y la constitución del discurso nacionalista en Venezuela.» Amérique Latine. Histoire et mémoire. Les cahiers ALHIM, 16. Disponible en http:alhim.revues.org/index.306o.html.

González Pérez, M. (2005). La idea de nación. En Marcos y Rueda (Eds.). Investigación interdisciplinaria: urdimbres y tramas (pp. 51-92). Bogotá: Cooperativa Editorial Magisterio. 
Greenfeld, L. (1990). The formation of the Russian National Identity. Comparative studies in society and history, 32(3), 549-591.

Greenfeld, L. (1992). Nationalism. Five road to modernity. Cambridge: Harvard University Press.

Greenfeld, L. (1994, febrero). Nationalism and Aggression. Theory and Society, 23(1) 79-130.

Greenfeld, L. (2006). Nationalism. Five road to the modernity. Cambridge: Harvard University Press.

Greenfeld, L. y Eastwood, J. (2007). National Identity. En Boix, C. (Ed.). The Oxford handbook of comparative politics (pp. 256-273). Oxford: Oxford University Press.

Greimas, A. J. (1971). Semántica estructural. Madrid Gredos.

Greimas, A. J. (1973). En torno al sentido; ensayos semióticos. Madrid: Fragua.

Gómez, A. (2001, enero 8). Oráculos, historiadores y ciudadanos. Analítica.com. Disponible en: En www.analitica.com/va/sociedad/articulos/8944181.asp.

Gómez, A. (2006). L'épée du Libertador dans l'idéologie des révolutionnaires bolivariens. Problemes d'Amérique, 6o, 95-114.

Hallbawchs, M. (1968). Memoria colectiva (traducción REIS). En La mémoire collective (pp. 209-219). Paris: Presses Universitaires de France.

Hébrard, V. (2006). El hombre de armas: de la heroización al mito. En Carrera Damas, G., Lomné, G. y Martinez, F. (Eds.). Mitos políticos en las sociedades andinas (pp. 281-300). Caracas: Editorial Equinoccio.

Hiernaux, J. P. (1977). L'institution culturelle. Méthode de description structurale. Louvain: Presses Universitaires de Louvain.

Hiernaux, J. P. (1996). Aprendre par l'erreur. Notes critiques concernant Piret et al. "L'analyse structurale". Louvain-la-neuve: Cahier Ronéo.

Hiernaux, J. P. (2008). Análisis estructural de contenidos y de modelos culturales. Aplicación a materiales voluminosos. En Suárez, H. J. (Coord.). El sentido y el método. Sociología de la cultura y análisis de contenido (pp. 67-119). México, D.F.: UNAM.

Hobsbawm, E. (1998). Naciones y nacionalismo desde 1780. Barcelona: Crítica.

Hobsbawm, E. y Ranger, T. (Ed). La invención de la tradición. Barcelona: Crítica.

Hoyos, G. (2006). La teoría de la acción comunicativa y las ciencias de la discusión. En Hoyos, G. y Vargas, G. La teoría de la acción comunicativa como nuevo 
paradigma de investigación en ciencias sociales: las ciencias de la discusión (pp. 199-228). Bogotá: Instituto Colombiano de Fomento a la Eduación Superior.

Jaffrelot, C. (1993). Modelos explicativos del origen de las naciones y del nacionalismo. En Delanoi, G. Teorías del nacionalismo (pp. 63-181). Barcelona: Paidós.

Keller, A. (1997). Las fortalezas aparentes. El caso de los actores políticos y sociales frente a los procesos de democratización y reformas económicas. En Mora y Araujo (Eds.). Los actores sociales y políticos en los procesos de transformación en América Latina (pp. 327-362). Caracas: CIEDLA.

Kornblith, M. (1996). Crisis y transformación del sistema político venezolano: nuevas y viejas reglas de juego. En Álvarez, A. El sistema político venezolano: crisis y transformaciones (pp. 1-23). Caracas: Universidad Central de Venezuela.

Krzymwicka, K. (2011). La formación del Estado nacional en Venezuela. En Bicentenario de la independencia en América Latina. Cambios y realidades (pp. 309-333). Lublin: Editorial de la Universidad Maria-Curie Sklo.

Kymlicka, W. (2004). Estados, naciones y culturas. Córdoba: Almuzara.

Laclau, E. (1985). Tesis acerca de la forma hegemónica de la polìtica. En Labastida, J. (Coord.) Hegemonía y alternativas políticas en América Latina (pp. 19-45). México: Siglo XXI.

Laclau, E. (2005). La razón populista. Buenos Aires: Fondo de cultura económico.

Laclau, E. (2006, septiembre-octubre). La deriva populista y la centroizquierda latinoamericana. Revista Nueva Sociedad, (205), 56-61.

Laclau, E. y Mouffe, C. (1987). Hegemonía y estrategia socialista. Hacia una radicalización de la democracia. Madrid: Siglo XXI.

Langue, F. (2006). Petróleo y revolución en las Américas. Las estrategias bolivarianas de Hugo Chávez. Revista Venezolana de Ciencia Política, (29), 127-152.

Langue, F. (2008). Les cendres des héroes. Nuevos Mundos. Mundos nuevos. Disponible en http://nuevomundo.revues.org/2902

Langue, F. (2009a). La Independencia de Venezuela, una historia mitificada y un paradigma heróico. Anuario de Estudios Americanos, 66(2), 245-276.

Langue, F. (2009b). De panteones cívicos e imaginarios políticos: los usos del pasado en la Revolución bolivariana. En Ramos Pismataro y Romero (Coords.). Hugo Chávez: una década en el poder (pp. 712-726). Bogotá: Universidad del Rosario. 
Langue, F. (2011). Reinvención del libertador e historia oficial de Venezuela. Araucaria. Revista Iberoamericana de Filosofía, Política y Humanidades, 13(25), 26-45.

Lavou Zoungbo, V. (1996). Discurso burgués y legitimación machista en Doña Bárbara de Rómulo Gallegos. Revista de crítica literaria latinoamericana, (43), 211-225.

Lazo Cividanes, L. (2011). Una vuelta al populismo clásico. El caso de Hugo Chávez. En Ramos, J. A. (Comp.). La revolución bolivariana. El pasado de una ilusión (pp. 123-143). Caracas: La hoja del norte.

Lenin, V. (s.f.). La revolución socialista y el derecho de las naciones a la autodeterminación. Andalucía: Espacio Revolucionario Andaluz.

Lenin, V. (2008). Tesis y adiciones sobre los problemas nacional y colonial. En Los cuatro primeros Congresos de la Internacional Comunista (pp. 167-185). Francia: Izquierda revolucionaria.

López Alves, F. (2003). La formación del Estado y la democracia en América Latina: 1830-1910. Bogota: Editorial Norma.

López- Maya, M. (2008). Venezuela: Hugo Chávez y el bolivarianismo. Revista Venezolana de Economía y Ciencias Sociales, 14(3), 55-82.

López Maya, M. (2008, junio). Venezuela: ascenso y gobierno de Hugo Chávez. Controversia, 190, 12-53.

López- Maya, M. (2010). Venezuela: once años de gestión de Hugo Chávez Frías y sus fuerzas bolivarianas (1999-2010). Revista Temas y debates, 14(20), 197-226.

Márquez, M. L. (2000). El neopopulismo en Venezuela. Revista Papel Político, 11, 131-146.

Márquez, M. L. (2004). Neopopulismo y chavismo. En Ahumada, C. y Angarita, T. (Eds.). La región andina: entre los nuevos populismo y la movilización social (pp. 65-123). Bogotá: Observatorio Andino.

Machillanda, J. (1989). Poder político y poder militar en Venezuela. Tesis no publicada para optar al título de Magíster en Estudios Políticos. Universidad Simón Bolívar.

Madriz, M. F. (2002). La noción del pueblo en el discurso populista. Revista Latinoamericana de Estudios del Discurso, 2(1), 69-92

Maldonado, C. E. (2009). La complejidad de los sistemas sociales: un reto para las ciencias sociales. Cinta de Moebio (36), 146-157.

Marin, L. (2009). Poder, representación e imagen. Prismas. Revista de Historia intelectual, 13, 135-153. 
Medina, M. (2001). El elegido Presidente Chávez. Un nuevo sistema político. Bogotá: Ediciones Aurora.

Medina, M. (2007). La revolución sin libreto. En Medina, M., López, M. y Lander, L. (Eds.). Chávez: una revolución sin libreto (pp. 11-27). Bogotá: Aurora.

Medina, M., López, M. y Lander, L. (Eds.). (2007). Chávez: una revolución sin libreto. Bogotá: Aurora.

Ministerio del Poder Popular para la Cultura. Despacho del Ministro (2011). Memoria 2010. Caracas: Ministerio del Poder Popular para la Cultura.

Ministerio del Poder Popular para la Cultura. Despacho del Ministro (2012). Memoria 2011. Caracas: Ministerio del Poder Popular para la Cultura.

Ministerio del Poder Popular para la Cultura. Despacho del Ministro (2013). Memoria 2012. Caracas: Ministerio del Poder Popular para la Cultura.

Mixon, L. (2009). Use of authoritarian charisma and national myth in the discourse of Hugo Chavez. Toward a critical model of the rhetorical analysis for political discourse of Hugo Chavez. Dissertaion. Virginia: Regent University.

Molero de la Cabeza, L. (2002). El personalismo en el discurso político venezolano. Un enfoque semántico y pragmático. Convergencia (28), 291-334.

Molero de la Cabeza, L. (2010). Crisis versus cambio en el discurso político venezolano de la primera década del siglo XXI: estrategias lingüístico-discursivas. Revista Latinoamericana de Estudios del Discurso, 10(1), 111-133.

Moore, B. (1973). Los orígenes sociales de la dictadura y la democracia. El señor y el campesino en la formación del mundo moderno. Barcelona: Península.

Mora García, J. P. (2006). Hermenéutica crítica de la historia del presente: la invención de la tradición en la revolución bolivariana. Dikaiosyne (17), 81-94

Morin, E. (2007). Sobre la interdisciplinariedad. Centre International de Recherches et études transdisciplinaires Boletín \#2.

Narvaja de Arnoux, E. (2008). El discurso latinoamericanista de Hugo Chávez. Buenos Aires: Biblos.

Nora, P. (1998). La aventura de Les lieux de mémoire. Revista Ayer (32), 17-34

Norden, D. (1998). Democracy and military control in Venezuela. From subordination to insurrection. Latin America Research Review, 33(2), 143-165.

Paramio, L. (2006, septiembre-octubre). Giro a la izquierda y regreso del populismo. Nueva Sociedad (205), 62-74. 
Pereira Almao, V. (2002). El movimiento V República en Venezuela: fuerzas y debilidades. Documento avance del proyecto de investigación "Cultura política y representación ideológica en el continuo izquierda-derecha”. Universidad de Zulia. Disponible en www.svs.osu.edu/jornadas/Pereira.pdf.

Pérez Agote, A. (1993). Las paradojas de la nación. Revista Española de investigaciones sociológicas (61), 7-21.

Pérez Benavides, A. C. (2012). Representaciones y prácticas en las zonas de misión: los informes de los frailes capuchinos. En Hering, M. y Pérez Benavides, A. C. (Eds.). Historia cultural desde Colombia.Categorías y debates (pp. 287-316). Bogotá: Universidad Nacional de Colombia.

Petkoff, T. (2011). El chavismo al banquillo. Pasado, presente y futuro de un proyecto político. Bogotá: Planeta.

Pino Iturrieta, E. (1998, abril-mayo). Necesidad y despotismo de los héroes. Revista Imagen abril- mayo. Disponible en: ftp://209.61.204.47/Bitbliotecarob/Bitblioteca/bitblioteca/epino/heroes.asp

Pino Iturrieta, E. (1999, noviembre 16). La tropelía de la República Bolivariana.Analítica.com. Prost, A. (1996). Doce lecciones sobre la historia. Madrid: Cátedra. Universitat Valencia.

Quintero, I. (1999, noviembre). El chavismo: ¿̇resurrección o muerte del 18 de octubre? Analítica.com.

Quintero, I. (1999, noviembre 28). Del Bolívar para todos al Bolívar para Chávez. El Nacional.

Quintero, I. (2010). Discurso pronunciado ante la Academia Nacional de la Historia. Caracas.

Ramos Jiménez, A. (2011). El liderazgo del nuevo comienzo. En La Revolución bolivariana. El pasado de una ilusión (pp. 97-121). Caracas: La hoja del norte.

Renan, E. (2000). ¿Qué es una nación? En Fernández Bravo, A. (Comp.). La invención de la nación. Lecturas de la identidad de Herder a Hommi Bhabha (pp. 27-52). Buenos Aires: Manantial.

República Bolivariana de Venezuela (2007). Líneas generales del Plan Económico y social de la Nación 2007- 2013. Caracas: República Bolivariana de Venezuela.

República Bolivariana de Venezuela. (2011, abril 9). Ministerio del poder popular para las Relaciones Exteriores. Lista de acuerdos sensibles a suscribirse durante la 
visita del comandante Presidente Hugo Chávez Frías a la República de Colombia. Disponible en: www.mre.gov.ve

Ricoeur, P. (1999). Historia y narratividad. Barcelona: Paidós.

Ricoeur, P. (2000a). La escritura de la historia y la representación del pasado. $2^{a}$ Conferencia Marc Bloch. Paris.

Ricoeur, Paul. (200ob). Narratividad, fenomenología y hermenéutica. Anàlisis 25, 189-207.

Ricoeur, P. (2004). Tiempo y Narración. Configuración del tiempo en el relato histórico. Tomo 1. México: Siglo XXI.

Ricoeur, P. (2010). La memoria, la historia, el olvido. Buenos Aires: Fondo de Cultura Económica.

Rojas, R. (2011a). Venezuela: fiesta, imaginario y nación. San Felipe, Yaracuy: Universidad Nacional Experimental de Yaracuy.

Rojas, R. (2011b). El retorno del héroe: el discurso político de Hugo Chávez y el proceso constituyente de Venezuela, 1999. En Venezuela: fiesta, imaginario político y nación (pp. 186-219). San Felipe: Universidad Nacional experimental de Yaracuy,.

Romero, J.E. (2001). El discurso político de Hugo Chávez (1996-1999). Espacio abierto, $10(2), 229-245$.

Romero, J. E. (2004). Hugo Chávez y la representación de la historia. Reflexión política, 146-169.

Romero, J. E. (2005a). Usos e interpretaciones de la historia de Venezuela en el pensamiento de Hugo Chávez. Revista Venezolana de Economía y Ciencias Sociales, 11 (2), 211-235.

Romero, J. E. (2005b). Discurso político, comunicación política e historia en Hugo Chávez. Revista Ambitos (13-14), 357-377.

Romero, J.E. (2012). El discurso político de cara a las elecciones 2012. Aporrea. Disponible en www.aporrea.com.

Romero, J. E. y Quiñones, Y. (2009). Discurso, poder e historia en el pensamiento de Hugo Chávez (1998-2009). En Ramos Pismataro y Romero (Comps.). Hugo Chávez: una década en el poder (pp. 218-236). Bogotá: Universidad del Rosario.

Romero, J. E. y Quiñones, Y. (2010). El pensamiento sociopolítico de Hugo Chávez: discurso, poder e historia. Cuadernos latinoamericanos, 21(38), 19-37.

Salamanca, L. (1997). Crisis de la modernización y crisis de la democracia en Venezuela. Caracas: Universidad Central de Venezuela. 
Salas, Y. (2004). La guerra del símbolo y espacio de poder. El caso Venezuela. En Grimson, A. La cultura en las crisis latinoamericanas (pp. 145-177). Buenos Aires: Clacso.

Salas, Y. (2005). la dramatización social y política del imaginario popular: el fenómeno del bolivarianismo en Venezuela. En Mato, D. (Comp.). Cultura, política y sociedad. Perspectivas Latinoamericanas (pp. 241-263). Buenos Aires: Clacso.

Saldarriaga, O. (2008a). Colombia. Lineamientos curriculares en ciencias sociales. En Suárez, J. H. (Coord.). El sentido y el método. Sociología de la cultura y análisis de contenido (pp. 145-170). México, D.F.: UNAM.

Saldarriaga, O. (2008b). Colombia. Evaluación de la construcción del conocimiento social en educación. Análisis estructural de sistemas de sentido en alumnos en ciencias sociales en colegios de Bogotá. En Suárez, J. H. (Coord.). El sentido y el método. Sociología de la cultura y análisis de contenido (pp. 171-210). México, D.F.: UNAM.

Santamaria, A. R. (2001). Los nacionalismos. De los origenes a la globalización. Barcelona: Edicions Bellaterra.

Skurski, J. (2000). The ambiguities of authenticity in Latin America: Doña Barbara and the construction of national identity. Poetics today, 15, 605-642.

Smith, A. (2000). Nacionalismo y modernidad . Madrid: Istmo.

Sommer, D. (2004). Ficciones fundacionales: las novelas nacionales de América Latina. México: Fondo de cultura económica.

Sparkes, A. C. y Devís, J. (2007). Investigación narrativa y sus formas de análisis: una visión desde la educación física y el deporte. En Pulido, S. y W. (Eds.). Educación, cuerpo y ciudad. El cuerpo en las interacciones e instituciones sociales (pp. 4369). Medellín: Funánbulos editores.

Spruyt, H. (2007). "War, trade and State formation” Oxford University Press pp. 73-90. En Stokes, S. y Boix, C. (Eds.). Oxford Handbook of comparative politics (pp. 211-235). Oxford: Oxford University Press.

Stalin, J. (1977). El Marxismo y la cuestión nacional. Barcelona: Anagrama.

Straka, T. (2009) ¿Hartos de Bolívar? La rebelión de los historiadores contra el culto fundacional. Boletín. Academia Nacional de Historia de Venezuela (365), 51-91.

Suárez, H. J. (Coord). (2008a). El sentido y el método. Sociología de la cultura y análisis de contenido. México, D.F.: El Colegio de Michoacán. Universidad Nacional Autónoma de México. 
Suárez, H. J. (2008b). El método de análisis estructural de contenido. Principios operativos. En Suárez, H. J. (Coord.). El sentido y el método. Sociología de la cultura y análisis de contenido (pp. 119-144). México, D.F.: UNAM.

Suárez, H. J. (2008c). Ensayo de análisis estructural de la fotografía cristera. En Suárez, H. J. (Coord.). El sentido y el método. Sociología de la cultura y análisis de contenido (pp. 281-298). México, D.F.: UNAM.

Taussig, M. (1995a). La magia del Estado: Maria Lionza y Simón Bolívar en la Venezuela contemporánea. En Gutiérrez et al. De palabra y obra en el Nuevo Mundo (pp. 489-517). México: Siglo XXI.

Taussig, M. (1995b). Maleficium: el fetichismo de Estado. En Un gigante en convulsiones. El mundo humano como un sistema nervioso en permanente emergencia (pp. 144-181). Barcelona: Gedisa.

Taussig, M. (1997). The magic of the State. London: Routkedge.

Thays, A. (2010). La metáfora conceptual en el discurso político venezolano: Rómulo Betancourt y Hugo Chávez. Revista Latinoamericana de Estudios del discurso, 10(1), 9-34.

Tillman, A. (2012). In the service of El Comandante. Bolivarian history and historians in Chávez's Venezuela. Ponencia Presentada en el Congreso de la Latin American Studies Association. San Francisco.

Tilly, C. (1992). Coerción, capital y los Estados europeos. Buenos Aires: Alianza Editorial. Todorov, T. y Ducrot O. (1995). Diccionario enciclopédico de las Ciencias del lenguaje. Buenos Aires: Siglo XXI Editores.

Toussaint, E. (2009). Luces y sombras en la Venezuela Bolivariana. Aporrea. Disponible en: http://www.aporrea.org/ideologia/a88188.htmlSafariHTML/Shell/ Open/Command

Trinkunas, H. (2001). Crafting civilian control. En Pion Berlin, D. (Ed.). Civil-military relations in Latin America. New analytical perspectives (pp. 161-193). Chapell Hill and London: The University of North Carolina Press.

Trikunas, H. (2002). The crisis in venezuelan civil-militar relations: From Punto Fijo to the Fifth Republic. Latin American Research Review, 37(1), 41-76

Valecillos, H. (1992). El reajuste neoliberal en Venezuela. Caracas: Monteavila.

Valencia Ramírez, C. (2005). Venezuela's bolivarian revolution: who are the chavistas. Latin American perspectives, 32(3), 79-97. 
Wallenstein, I. (1991a). Universalismo, racismo y sexismo, tensiones ideológicas del capitalismo. En Wallenstein, I. y Balibar, E. (Eds.). Raza, Nación y clase (pp. 49-63). Madrid: Iepala textos.

Wallerstein, I. (1991b). La construcción de los pueblos: racismo, nacionalismo y etnicidad. En Wallenstein, I. y Balibar, E. (Eds.). Raza, Nación y clase (pp. 111-134). Madrid: Iepala textos.

Wallerstein, I. y Balibar, E. (1991). Raza, nación y clase. Madrid: IEPALA.

Waltz, K. N. (1959). El hombre, el estado y la guerra. Buenos Aires: Nova.

Weber, M. (1996). Economía y Sociedad. México: Fondo de Cultura económica.

Weyland, K. (2003, diciembre). Neopopulism and neoliberalism in Latin America. Third World Quartely, 24(6), 1095-1115.

White, H. (2005). Metahistoria. La imaginación histórica en la Europa del siglo XIX. México: Fondo de Cultura económica.

Zago A. (1998). La rebelión de los ángeles. Caracas: Warp Ediciones.

Zermeño, S. (1985). Los referentes históricos y sociológico de la hegemonía. En Labastida, J. (Coord.). Hegemonía y alternativas políticas en América Latina (pp. 251-279). México: Siglo XXI. 